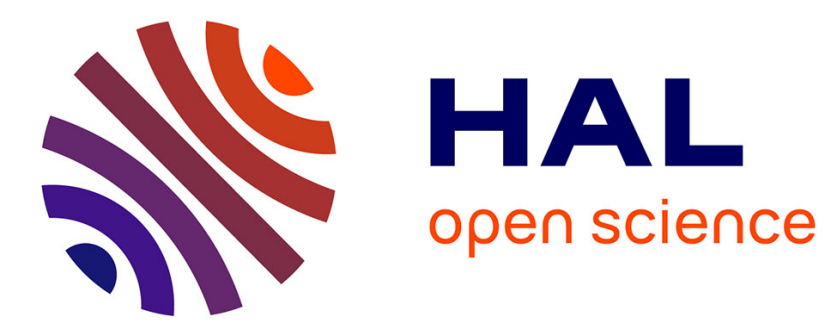

\title{
High-frequency transducer for MR-guided FUS
}

Spiros Kotopoulis, Han Wang, Sandy Cochran, Michiel Postema

\section{To cite this version:}

Spiros Kotopoulis, Han Wang, Sandy Cochran, Michiel Postema. High-frequency transducer for MR-guided FUS. Biomedical Engineering = Biomedizinische Technik, 2012, 57 (Suppl. 1), pp.972. 10.1515/bmt-2012-4135 . hal-03193199

\section{HAL Id: hal-03193199 \\ https://hal.science/hal-03193199}

Submitted on 11 Apr 2021

HAL is a multi-disciplinary open access archive for the deposit and dissemination of scientific research documents, whether they are published or not. The documents may come from teaching and research institutions in France or abroad, or from public or private research centers.
L'archive ouverte pluridisciplinaire HAL, est destinée au dépôt et à la diffusion de documents scientifiques de niveau recherche, publiés ou non, émanant des établissements d'enseignement et de recherche français ou étrangers, des laboratoires publics ou privés. 


\section{High-frequency transducer for MR-guided FUS}

Spiros Kotopoulis, Department of Physics and Technology, University of Bergen, Bergen, Norway;

Han Wang, IMSaT, University of Dundee, Dundee, Scotland;

Sandy Cochran, IMSaT, University of Dundee, Dundee, Scotland;

Michiel Postema, Department of Physics and Technology, University of Bergen, Bergen, Norway; and Carnegie Physics Laboratory, School of Engineering, Physics and Mathematics, University of Dundee, Scotland.

e-Mail: Michiel.Postema@ift.uib.no

\section{Introduction}

High-intensity focused ultrasound is finding increasing therapeutic use. However, the frequencies at which it operates are typically limited to below $5 \mathrm{MHz}$, preventing research into therapy with ultrahigh spatial precision. A reason for this is that the design and fabrication of high-frequency biomedical ultrasound transducers to produce high intensities is an engineering challenge, especially for operating frequencies above $30 \mathrm{MHz}$, primarily because of the acoustic impedance mismatch and the high attenuation of water of $6 \mathrm{~dB} / \mathrm{cm}$ at $50 \mathrm{MHz}$ leading to a low penetration depth. Commonly used materials such as PZT do not have the ability to produce a high enough intensity, due to de-poling or cracking. A potential application of high-intensity high-frequency ultrasound is non-invasive microsurgery.

\section{Methods}

To overcome these problems, we used Y-36o Lithium Niobate (LiNbO3). This crystal has a high Curie temperature and is much more difficult to de-pole at high-power inputs. In addition, Y-36o LiNbO3 has a resonant frequency of 3.3 $\mathrm{MHz}$ mm-1, thus allowing for much thicker elements at higher frequencies compared to PZT. A bowl transducer was manufactured using a total of $70.5-\mathrm{mm}$ thick elements (4 hexagonal and 5 pentagonal) with a maximum width of 25 $\mathrm{mm}$. The bowl had a curvature radius of $50 \mathrm{~mm}$. The transducer was microballoon-backed in order to simplify the manufacturing process. The pentagonal elements were linked and driven by a 50-dB amplifier, whereas the hexagonal elements were linked and driven by a 55- $\mathrm{dB}$ amplifier. To test the available working frequency; single element transducers were manufactured with element thickness ranging from $500 \mu \mathrm{m}$ to $200 \mu \mathrm{m}$, having working frequencies between $6.6 \mathrm{MHz}$ and $20 \mathrm{MHz}$.

\section{Results}

The multi-element focused transducer generated a modulated sound field with an enveloped wavelength of $550 \mathrm{kHz}$ at a frequency of 6.6 MHz with a maximum peak-to-peak pressure of $24.3 \mathrm{MPa}$; equivalent to mechanical index of 4.7. The modulation could be varied by changing the phase of either the pentagonal or hexagonal linked elements. The microballoon-backed transducers had a 5\% reduced acoustic output compared to the air-backed transducer. Singleelement transducers produced a maximum peak-to-peak pressure of $14 \mathrm{MPa}$ at $6.3 \mathrm{MHz}$ in the acoustic focus at $12 \mathrm{~mm}$. These transducers were capable of producing over $6 \mathrm{MPa}$ and $4 \mathrm{MPa}$ at the 3rd and 5th harmonics, respectively, corresponding to frequencies of $21 \mathrm{MHz}$ and $35 \mathrm{MHz}$.

\section{Conclusion}

We have established that manufacturing a high frequency, high intensity, multi-element, focused ultrasound transducer using $\mathrm{LiNbO}_{3}$ is feasible. We have also shown it is possible to use the resonant frequency and up to the $5^{\text {th }}$ harmonic to achieve higher working frequencies. 